\title{
Energy saving in wastewater treatment plants
}

\author{
Natalia Ciobanu* \\ Technical University of Moldova, 39 Dacia avenue, Chisinau, Republic of Moldova
}

\begin{abstract}
This paper uses data from the Chisinau Wastewater Treatment Plant (WWTP) (2018 year) to analyze the potential for energy recovery from wastewater treatment plant via anaerobic digestion with biogas utilization with electricity generation. These energy recovery strategies could help offset the electricity consumption of the wastewater treatment plants and represent possible areas for sustainable energy policy implementation. We estimate that anaerobic digestion could save approximately 14,444,918 kWh annually in Chisinau WWTP. Anaerobic digestion is widely considered as an environmentally friendly technology for sewerage sludge. This study aims to highlight the potential as well as to provide a starting point for further studies regarding the treatment as sewerage sludge using anaerobic digestion in Republic of Moldova and recovery energy that could further reduce electricity cost and reduction of sludge cake.
\end{abstract}

Keywords: wastewater treatment, energy, sludge, anaerobic digestion, biogas.

\section{Introduction}

Wastewater collected from municipalities and communities must ultimately be returned to receiving waters or to the land or reused [1]. Chisinau WWTP has been constructed in successive phases and is operated by "Apa Canal Chisinau" (ACC). The wastewater flow rate was approximately 435 thousand $\mathrm{m}^{3} /$ day (yearly average) with average chemical oxygen demand (COD), 5 day biological oxygen demand $\left(\mathrm{BOD}_{5}\right)$, and total suspended solids (TSS) concentrations of $900 \mathrm{mg} / 1,300 \mathrm{mg} / 1$, and $500 \mathrm{mg} / \mathrm{l}$ respectively. Chisinau WWTP has been largely oversized and is currently running at only one third of its capacity (142 thousand $\mathrm{m}^{3} /$ day). The wastewater treatment process features the conventional steps of a medium-load activated sludge plant modified with contact stabilization tank for the aeration of returned activated sludge to the head of secondary treatment. The lack of an appropriate sludge treatment line combined with extremely poor conditions of the works and pieces of equipment and the absence of online sensors and of control systems impede the optimal operation of the plant. The current practices in sludge management by dewatering and drying in geotubes must be changed since they cause significant odor problems in the city especially in nearby settlements.

This is a study of analyzing scenario in terms of their technological and economical feasibilities focusing on the sludge management processes to increase the sustainability of the WWTP operation in Chisinau by using biogas recovered from waste activated sludge (WAS). The formation of biogas composed of mainly $\mathrm{CH}_{4}$ and $\mathrm{CO}_{2}$ in anaerobic digester

\footnotetext{
*Corresponding author: natalia.ciobanu@fua.utm.md, ciobnata@hotmail.com
} 
processing WAS as the substrate is proposed for rendering organic load produced in the secondary treatment and reducing solids content of WAS.

\section{Methods}

\subsection{Data collection}

The existing Chisinau Wastewater Treatment Plant dates back from the 70s and was built in several stages although it has never worked at full capacity according to the best of our knowledge. About 35-40 \% of the works are being used currently. The treatment of wastewater in Chisinau WWTP takes place in several stages as follows:

a) The Preliminary Treatment consists of two physical operations: screening and sand removal. Screening (six pieces, 10.5 or $16 \mathrm{~mm}$ for spacing) removes large solids, which are retained by the screens. The main reasons for screening are to protect the pumps and pipe works, downstream treatment units and tanks. The sand is removed by sedimentation through grit chamber (with four sections).

b) The Primary Treatment consists of primary settling process. Primary settling tanks (4 cylindrical tanks with a volume of $4500 \mathrm{~m}^{3}$ each) allow solids to settle gravimetrically with the settling velocity of $0.7 \mathrm{~m} / \mathrm{s}$ minimum. Primary sludge is transferred directly to geotubes to be dewatered.

c) The Secondary Treatment is a conventional activated sludge process (aeration and secondary settling) modified by contact stabilization of returned activated sludge (RAS) which is $70-80 \%$ to maintain the bacterial population in the reactor. There are currently 6 aeration tanks in operation with $\left(2-22500 \mathrm{~m}^{3}, 4-12500 \mathrm{~m}^{3}\right)$ with $10-15$ days solids retention time (SRT). The secondary settling tanks (volume $4500-9000 \mathrm{~m}^{3}$ each, four work out of eight) remove mixed liquor suspended solids (MLSS) produced in the aeration tanks by gravitational force. The clarified wastewater is discharged to the receiving water body (Bac River) and sludge is dewatered in geotubes.

d) The Sludge Management is simply dewatering of primary and secondary sludge in geotubes followed by landfills. The mixture of primary and secondary sludge used to be stored directly on sludge platforms (32 ha) for dehydration, which generated serious odor problems. The geotubes were implemented in 2009 as a quick and easy attempt to mitigate odor issues generated by the sludge platforms and it proved to be quite efficient in odor removal. Sludge is pumped into the geotubes and are added the polymers, which makes the solids bind together and water separate. Clear effluent water simply drains from the geotube through the small pores in the specially engineered textile. The decanted water is returned to the head of plant. After the final cycle of filling and dewatering, the solids remain in the bag and continue to density due to desiccation as residual water vapor escapes through the fabric. Volume reduction can be as high as 90 percent. When full, the geotubes (appr.600 $\mathrm{kg}$ each) and sludge cake are deposited at a landfill. Thus, capital cost of sludge management can be estimated as 391,308.8 €/year (160 Geotubes) [2]. After dewatering process, geotubes are opened and the sludge cake is transferred by trucks to a landfill site. The geotubes generated approximately $500,768.30 \mathrm{~m}^{3} /$ year of sludge in 2018 .

Nowadays, the Chisinau WWTP is powered with electricity $100 \%$ from the grid. The main power consumption apparatus in the plant are pumps and blowers. All other auxiliary power needs such as lighting and potable water pumps are also supplied from the grid. This data are essential for predicting the energy requirements for an alternative power system before doing an upgrade. The average yearly was calculated as $19,450,795 \mathrm{kWh}$ and cost including all taxes was 1,623,436.073 Euro/year or 0.083 Euro per kWh. For a 24 hour 
period the power consumption for the Chisinau WWTP was estimated 53,310 kWh. The electricity consumption of the individual units is shown in Table 2.1, this data indicate that the blowers consumed the highest amount of electricity.

Table 2.1. Evaluation of equipment electrical consumption by current operation

\begin{tabular}{|l|l|c|c|}
\hline No & \multicolumn{1}{|c|}{ Unit/Equipment name } & $\begin{array}{c}\text { Electricity consumption, } \\
\mathrm{kWh} / \text { day }\end{array}$ & $\begin{array}{c}\text { Percentage of energy } \\
\text { consumption, } \%\end{array}$ \\
\hline 1. & Blower & 39,500 & 74 \\
\hline 2. & Main Station Pump & 13,810 & 26 \\
\hline 3. & Return sludge pump & & \\
\hline
\end{tabular}

\subsection{Two case scenarios}

There are two scenarios investigated for the Chisinau WWTP focused on sludge production and its management including current operation to determine the best alternative with the maximum energy savings. The scenario is designed to employ anaerobic digestion in sludge management and mass and energy balance calculations and analyses are described in this section.

CASE 1: Current wastewater treatment operation. The current operation of the Chisinau WWTP is described in Section 2.1 in detail. The mass flow of solids (kg/day) is calculated using the average yearly flow rate $\left(141,400 \mathrm{~m}^{3} /\right.$ day) and the concentration of TSS $(74,845.85 \mathrm{~kg} / \mathrm{d}$ ) in untreated wastewater (Figure 2.1$)$. The measured values were used when available in mass balance calculations. There is $1,372 \mathrm{~m}^{3} /$ day of sludge production mainly composed of primary settlings ( $>95 \%$ wet volume), is discharged to geotubes for the dewatering process. The removal efficiency of TSS and $\mathrm{BOD}_{5}$ is determined as 95 and $96 \%$ respectively for the year of 2018 (see Table 2.2). The energy consumption for the treatment of $1 \mathrm{~m}^{3}$ wastewater is $0.380 \mathrm{kWh} / \mathrm{m}^{3}$, which is similar to the energy used to treat $1 \mathrm{~m}^{3}$ of wastewater (no industrial input) by secondary treatment; such as, $0.485 \mathrm{kWh} / \mathrm{m}^{3}$ in Slovakia [3], $0.420 \mathrm{kWh} / \mathrm{m}^{3}$ in Sweden [4], and $0.304 \mathrm{kWh} / \mathrm{m}^{3}$ in Japan [5]. The average energy consumption of using an activated sludge system for the treatment of wastewater has been reported as $0.34 \mathrm{kWh} / \mathrm{m}^{3}$ in U.S.A. [6].

Table 2.2. Treatment performances and the quality of the treated effluent (average values for the period from 01.01.2018 until 12.31.2018)

\begin{tabular}{|l|c|c|c|c|c|}
\hline Parameters & $\begin{array}{c}\text { Influent } \\
\text { WWTP }\end{array}$ & $\begin{array}{c}\text { Maximum } \\
\text { allowable } \\
\text { concentration } \\
\text { in WWTP [7] }\end{array}$ & $\begin{array}{c}\text { Effluent } \\
\text { WWTP }\end{array}$ & $\begin{array}{c}\text { Maximum } \\
\text { allowable } \\
\text { concentration at } \\
\text { the discharge in } \\
\text { the river Bac [8,9] }\end{array}$ & $\begin{array}{c}\text { Minimum } \\
\text { removal } \\
\text { rate } \\
\text { \% }\end{array}$ \\
\hline $\mathbf{C O D , ~} \mathrm{mg} / \mathrm{l}$ & 967.79 & 500 & 83.98 & 125.0 & 91.32 \\
\hline $\mathbf{B O D} \mathbf{5}, \mathrm{mg} / \mathrm{l}$ & 299.20 & 225 & 13.41 & 25.0 & 95.51 \\
\hline $\mathbf{T S S}, \mathrm{mg} / \mathrm{l}$ & 529.32 & 350 & 26.97 & 35.0 & 94.90 \\
\hline $\mathbf{p H}$ & 7.653 & $6.5-8.5$ & 7.615 & $6.5-8.5$ & - \\
\hline $\mathbf{T},{ }^{\circ} \mathrm{C}$ & 18.641 & $8-30$ & 19.534 & 30 & - \\
\hline $\mathbf{T K N}, \mathrm{mg} / \mathrm{l}$ & 63.031 & - & 28.139 & 10.0 & 55.0 \\
\hline $\mathbf{N H}, \mathrm{mg} / 1$ & 41.044 & 30.0 & 21.547 & 2.0 & 47.5 \\
\hline $\mathbf{P}, \mathrm{mg} / \mathrm{l}$ & 12.768 & 5.0 & 3.491 & 2.0 & 73.0 \\
\hline $\mathbf{N}, \mathrm{mg} / 1$ & 63.400 & - & 30.822 & 15.0 & 51.0 \\
\hline
\end{tabular}

In Figure 2.1 is shown a schematic diagram of activated sludge process with wasting from the sludge return line on current operation plant. 
Table 2.3. Monthly average of sludge in Chisinau WWTP (2018)

\begin{tabular}{|l|r|}
\hline \multicolumn{1}{|c|}{ Months } & \multicolumn{1}{c|}{$\begin{array}{c}\text { Sludge flow, } \\
\text { m3/day }\end{array}$} \\
\hline January & $1,402.23$ \\
\hline February & $1,207.34$ \\
\hline March & $1,019.52$ \\
\hline April & 976.15 \\
\hline May & $1,226.69$ \\
\hline June & 951.18 \\
\hline July & 689.95 \\
\hline August & 948.47 \\
\hline September & 985.33 \\
\hline October & $1,487.14$ \\
\hline November & $2,565.25$ \\
\hline December & $2,786.29$ \\
\hline 2018 average & $\mathbf{1 , 3 4 0 . 3 2}$ \\
\hline
\end{tabular}

As mentioned in p.2.1, in the Chisinau WWTP, dewatering sludge is accumulated on the sludge platforms (32 ha), where during the last years thousands cubic meters of sludge have been collected (only in 2018 about $500,768 \mathrm{~m}^{3} /$ day, see the table 2.2 ). This sludge is one of the sources of unpleasant odor that has taken over the city of Chisinau in the last 3-4 years. In 2009, geotubes were purchased as a temporary solution, but it turned into a long-term problem, for which Local Authorities did not find a solution regarding its use. The main issues of the Chisinau WWTP are following: (1) The current wastewater treatment performances of the plant do not comply with proposed discharge limits for all parameters; (2) The current energy consumption from the grid can be replaced with other sources; (3) The lack of modern sludge treatment facilities formed in the wastewater treatment process; (4) The lack of a strategy for using dewatering sludge.

Despite producing a massive amount of sewerage sludge annually, the utilization of sewerage sludge in Moldova did not get as much attention or progress as seen in other regions. The current state of sewerage sludge treatment sees it primary being used for landfill.

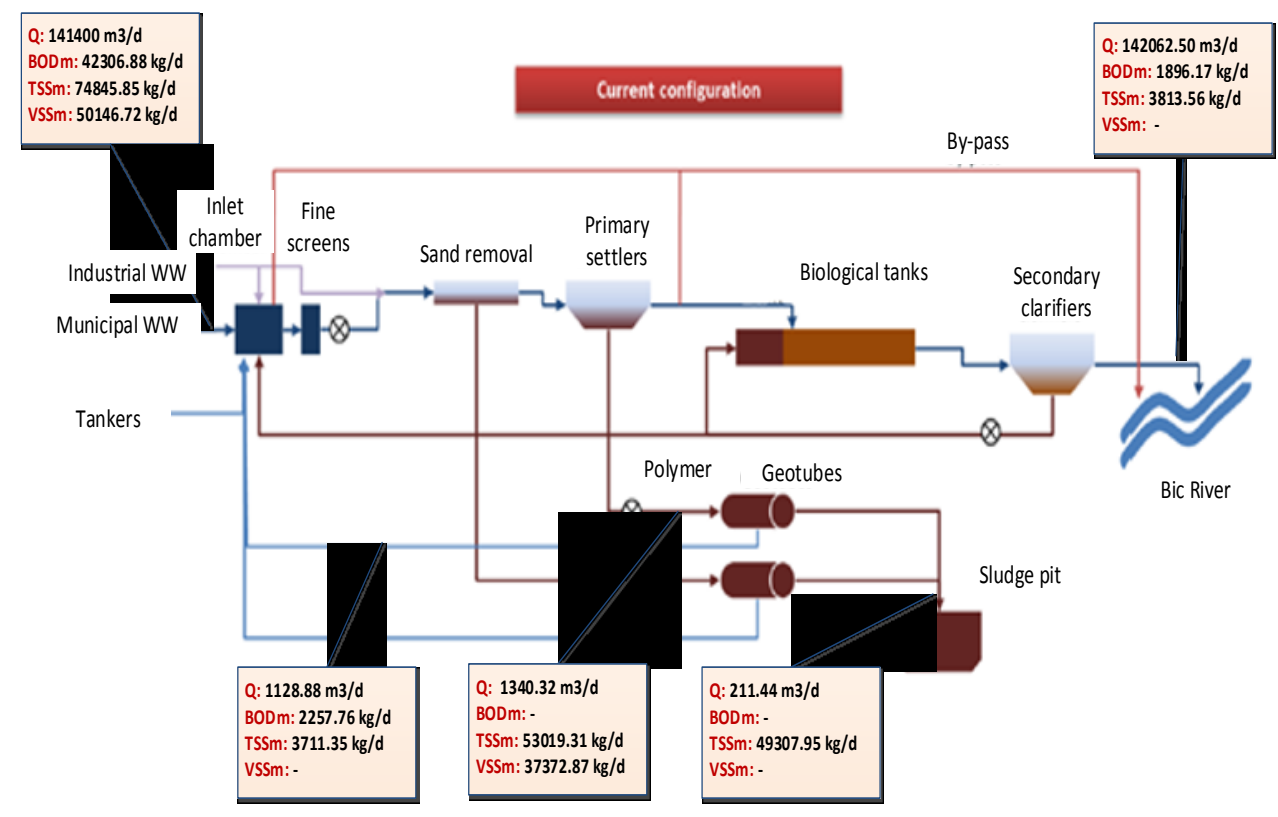

Fig. 2.1. Mass balance based on current operation of Chisinau WWTP

CASE 2: Wastewater treatment operation with anaerobic digestion of sewage sludge. Anaerobic digestion (AD) is one of the most widely used stabilization technologies. During $\mathrm{AD}$, a combustible gaseous mixture composed principally of $\mathrm{CO}_{2}$ and $\mathrm{CH}_{4}$ is produced by 
biological activity [10], investing sludge with commercial value as a bioenergy source. $\mathrm{AD}$ is a complex biochemical process that involves the action of microorganisms forming syntrophic consortia. It follows four fundamental steps: hydrolysis, acidogenesis, acetogenesis and methanogenesis. The hydrolysis step degrades both insoluble organic material and high molecular weight compounds such as lipids, polysaccharides, proteins and nucleic acids, into soluble organic substances. The components formed during hydrolysis are further split during acidogenesis, the second step. The third stage in AD is acetogenesis, where the higher organic acids and alcohols produced by acidogenesis are further digested by acetogens to produce mainly acetic acid as well as $\mathrm{CO}_{2}$ and $\mathrm{H}_{2}$. The final stage of methanogenesis produces methane by two groups of methanogenic bacteria: the first group split acetate into methane and carbon dioxide and the second group uses hydrogen as electron donor and carbon dioxide as acceptor to produce methane $[1,11]$. Previous studies by the Biosystems and Agricultural Engineering Department at Michigan State University demonstrated that many things can be done at the $\mathrm{AD}$ in order to save energy and one of them is by producing biogas $[12,13,14,15,16]$.

The goal of this paper is to reduce the amount of sludge, that needs to be disposed and the most widely employed method for sludge treatment is anaerobic digestion. The treatment of wastewater sludge, from primary and secondary treatment steps, consists of two main phases: in the $1^{\text {st }}$ step, all incoming flows of sludge are combined, and the mixture is heated to a mild temperature to accelerate biological conversion, which the mixture is allowed to undergo digestion. In further processes, the settled sludge is dewatered for, to separate as much water as possible to decrease the volume of sludge.

The simulation of the AD was based on the real data (2018 year) collected from Chisinau WWTP. A good approach to estimating solids is to prepare a material mass balance for the entire Chisinau WWTP. A material balance is prepared for the key components of flow, $B O D$ and TSS. In addition, I have been developing a solids mass balance with $\mathrm{AD}$, and all the calculations are done using Microsoft Excel, as shown in Figure 2. 2.

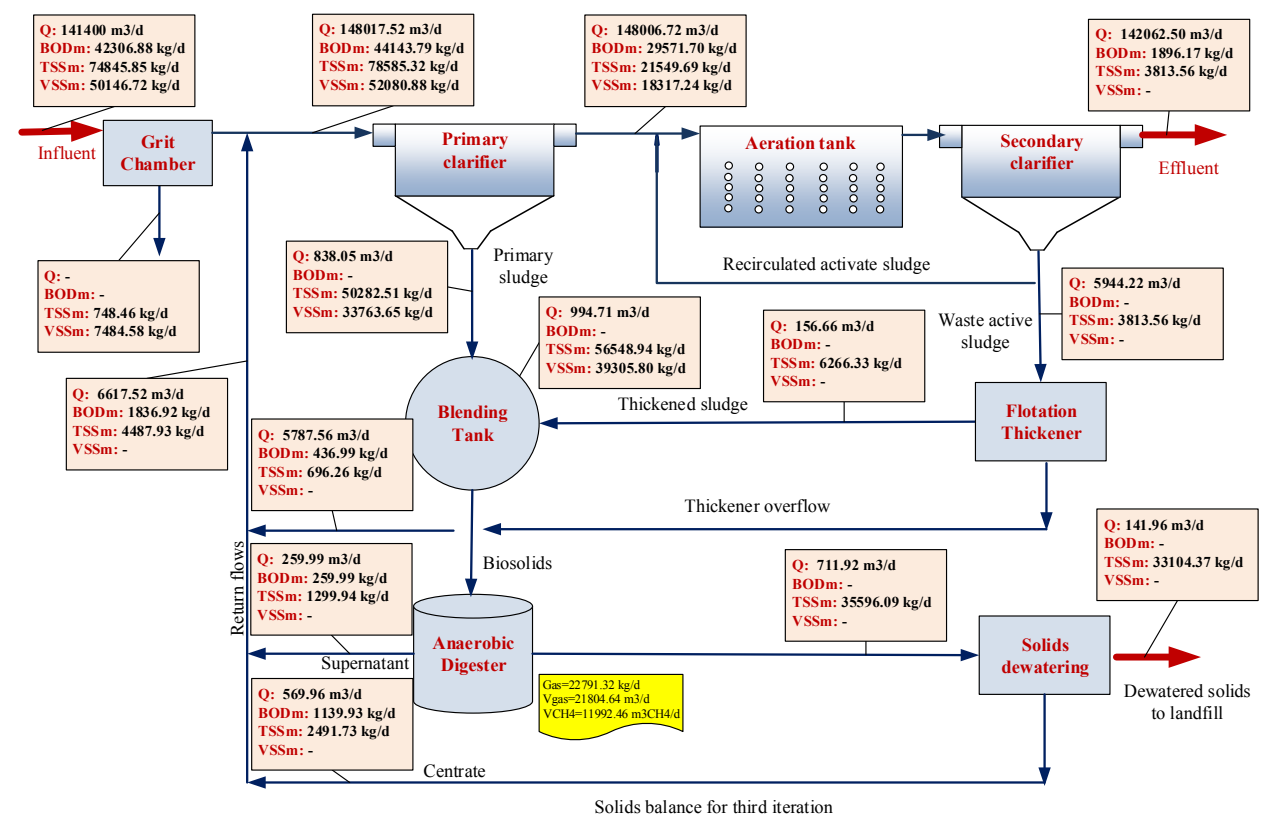

Fig. 2.2. Mass balance based on actual condition with anaerobic digester 
As a result of the third iteration of mass balance, we can see the daily production of sludge $994.7 \mathrm{~m}^{3} /$ day and biogas $21,804.46 \mathrm{~m}^{3}$ /day Figure 2.3 and gas production 11,992.46 Figure 2.4.

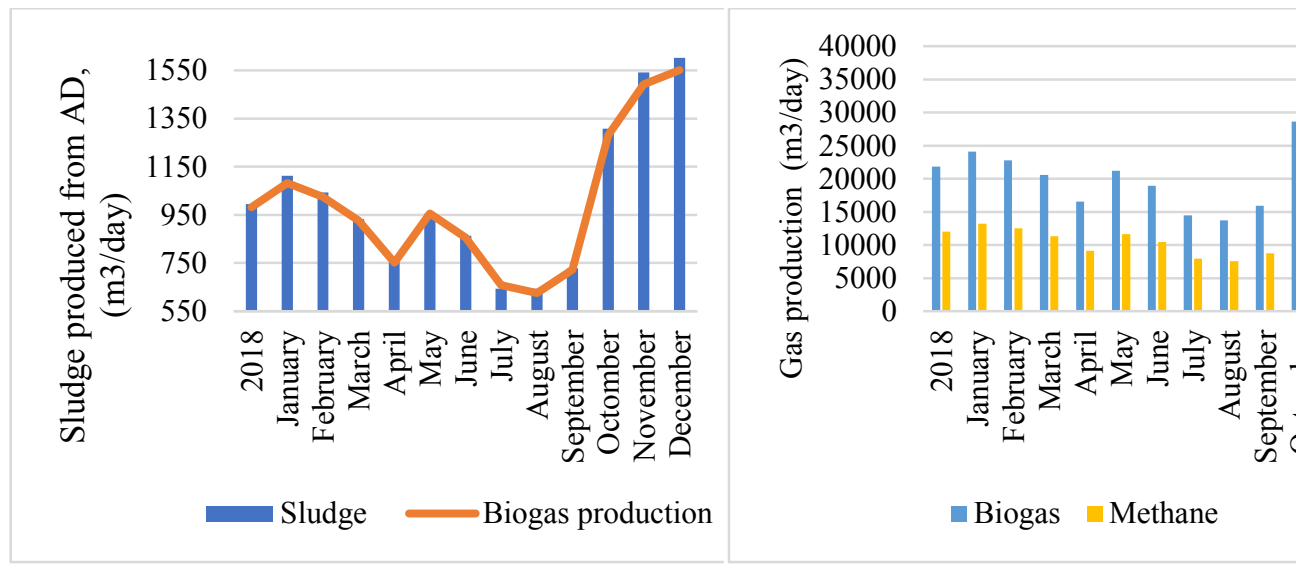

Fig. 2.3 Annual monthly profile of Sludge and Biogas Generation

Fig. 2.4 Daily gas and methane (\%55 of biogas is methane)

The current state regarding sewage sludge in Moldova is reviewed, with activities around other regions including for comparison. Challenges and tasks faced when treated sewerage sludge using anaerobic digestion in Moldova are discussed, with anaerobic co-digestion which would be include food waste, suggested as a possible approach. This study aims to provide a greater understanding as well as a starting point for further study regarding the future aspect of utilizing sewage sludge in Moldova. Sludge digestion would be very beneficial for the following reasons $[1,11,17,18]$ :

- Reduces the emissions of greenhouse gases (GHG), has a green image and is one of the best available technologies for sludge treatment;

- Reduces the volume of sludge, which consequently reduces the associated costs of downstream sludge treatment. That solution is financially relevant on a long term basis for large WWTPs;

- Production of energy. During anaerobic fermentation, the bacteria themselves are separating the energetic content of the sludge (transformed into methane gas) from the water. This is the main advantage of sludge digestion. No energy is consumed to recover the energy of the sludge itself, except for a very small percentage required for the heating of the digester.

\section{Results and discussion}

Most of the WWTPs are designed to meet a demand for the effluent quality without consideration of energy requirements. According to the European Benchmarking Cooperation [19], the average electricity consumption for wastewater treatment was 33.4 $\mathrm{kWh} / \mathrm{PE}$. The WWTP [20] shows the energy consumption in Europe at wastewater treatment plants by means of activated sludge at the level of $0.15-0.7 \mathrm{kWh} / \mathrm{m}^{3}$ often representing over $50 \%$ of the total site energy demand.

Energy efficiency of WWTP is of increasing interest, not only due to economic but also due to environmental aspects. Hence, the optimization of energy consumption and generation in WWTPs is an important topic. Examples for energy self-sufficient WWTPs in the world are described in [21]. 
A mass and energy balance were conducted to evaluate the system performance. The operational parameters for current WWT plant and anaerobic digester are listed in table 2.4 and 2.5. The total of sludge produced from Chisinau WWTP is $1,371.97 \mathrm{~m}^{3} /$ day and the total electricity consumption per day is $53,310 \mathrm{kWh}$. The AD system generated $22,792 \mathrm{~kg} /$ day, approximately $39,575 \mathrm{kWh} /$ day.

Table 2.4. Main results of the statistical analysis at Chisinau WWTP. Analysis section

\begin{tabular}{|c|c|c|c|c|c|}
\hline No & & Unit & Value & Unit & Value \\
\hline 1. & Wastewater flow & $\mathrm{m}^{3} / \mathrm{d}$ & 141,400 & $\mathrm{~m}^{3} /$ year & $51,594,337$ \\
\hline \multirow[t]{3}{*}{2.} & Total sludge at WWTP & $\mathrm{m}^{3} / \mathrm{d}$ & $1,371.97$ & $\mathrm{~m}^{3} /$ year & $500,768.30$ \\
\hline & a. $\quad$ Primary sludge & $\mathrm{m}^{3} / \mathrm{d}$ & 1331,56 & $\mathrm{~m}^{3} /$ year & $486,018.31$ \\
\hline & $\begin{array}{ll}\text { b. Waste activated } \\
\text { sludge }\end{array}$ & $\mathrm{m}^{3} / \mathrm{d}$ & 40.41 & $\mathrm{~m}^{3} /$ year & $14,749.99$ \\
\hline 3. & $\begin{array}{l}\text { Total amount sludge to } \\
\text { dewatering }\end{array}$ & $\mathrm{m}^{3} / \mathrm{d}$ & $1,340.32$ & $\mathrm{~m}^{3} /$ year & $489,216.8$ \\
\hline \multirow[t]{3}{*}{4.} & $\begin{array}{l}\text { Total Electricity } \\
\text { consumption }\end{array}$ & $\mathrm{kWh} / \mathrm{d}$ & 53,310 & $\mathrm{kWh} /$ year & $19,450,795$ \\
\hline & a. pumping & $\mathrm{kWh} / \mathrm{d}$ & 13,810 & $\mathrm{kWh} /$ year & $5,036,254$ \\
\hline & b. treatment & $\mathrm{kWh} / \mathrm{d}$ & 39,500 & $\mathrm{kWh} /$ year & $14,414,541$ \\
\hline 5. & $\begin{array}{l}\text { Electricity consumption to } \\
\text { remove } \mathbf{1} \mathrm{kg} \mathrm{CBO}_{5}\end{array}$ & $\begin{array}{r}\mathrm{kWh} / 1 \mathrm{kgCBO} 5 \\
\text { per day }\end{array}$ & 1.69 & $\begin{array}{r}\mathrm{kWh} / 1 \mathrm{kgCBO} 5 \\
\text { per year }\end{array}$ & 1.69 \\
\hline 6. & $\begin{array}{l}\text { Electricity consumption to } \\
\text { treat } 1 \mathrm{~m}^{3} \text { water }\end{array}$ & $\mathrm{kWh} / \mathrm{d}$ & 0.38 & $\mathrm{kWh} /$ year & 0.38 \\
\hline \multirow[t]{2}{*}{7.} & Expenses for electricity & lei MD/month & $2,917,619.25$ & lei MD/year & $35,011,431$ \\
\hline & & €uro/month & $135,286.339$ & €uro/year & $1,623,436.073$ \\
\hline 8. & Geotubes & Pieces/year & 160 & €uro/year & $391,308.8$ \\
\hline \multirow[t]{2}{*}{9.} & Polymer & $\mathrm{kg} /$ year & 19,825 & lei MD/year & $1,467,087.75$ \\
\hline & & & & €uro/year & $73,911.68$ \\
\hline
\end{tabular}

Table 2.5. Sludge management data in Chisinau WWTP modified by the addition of Flotation Thickener, Anaerobic Digestion, and Sludge dewatering processes (data from year 2018)

\begin{tabular}{|l|l|r|r|r|r|}
\hline No & & \multicolumn{1}{c|}{ Unit } & \multicolumn{1}{c|}{ Value } & \multicolumn{1}{c|}{ Unit } & \multicolumn{1}{c|}{ Value } \\
\hline 1. & $\begin{array}{l}\text { Total amount of sludge } \\
\text { produced from WWTP }\end{array}$ & $\mathrm{m}^{3} / \mathrm{d}$ & 994.70 & $\mathrm{~m}^{3} /$ year & $363,065.50$ \\
\hline & a) primary clarifier & $\mathrm{m}^{3} / \mathrm{d}$ & 838.04 & $\mathrm{~m}^{3} /$ year & $305,884.60$ \\
\hline & b) secondary clarifier & $\mathrm{m}^{3} / \mathrm{d}$ & 156.66 & $\mathrm{~m}^{3} /$ year & $57,180.90$ \\
\hline 2. & $\begin{array}{l}\text { Total amount of sludge } \\
\text { sent to dewatering }\end{array}$ & $\mathrm{m}^{3} / \mathrm{d}$ & 711.92 & $\mathrm{~m}^{3} /$ year & $259,851.49$ \\
\hline 3. & $\begin{array}{l}\text { Volume of mass of water } \\
\text { from sludge dewatering } \\
\text { process }\end{array}$ & $\mathrm{m}^{3} / \mathrm{d}$ & $6,617.52$ & $\mathrm{~m}^{3} /$ year & $2,415,393.80$ \\
\hline 4. & Amount of sludge cake & $\mathrm{m}^{3} / \mathrm{d}$ & 141.96 & $\mathrm{~m}^{3} /$ year & $51,814.30$ \\
\hline 5. & Amount of Gas & $\mathrm{kg} / \mathrm{d}$ & $22,791.32$ & $\mathrm{~kg} /$ year & $8,318,831.80$ \\
\hline 6. & $\begin{array}{l}\text { Amount of Biogas } \\
\text { production }\end{array}$ & $\mathrm{m}^{3} / \mathrm{d}$ & $21,804.64$ & $\mathrm{~m}^{3} /$ year & $7,958,629.30$ \\
\hline 7. & Amount of Methan & $\mathrm{m}^{3} \mathrm{CH} 4 / \mathrm{d}$ & $11,992.46$ & $\mathrm{~m}^{3} \mathrm{CH}_{4} /$ year & $4,377,247.90$ \\
\hline 8. & $\begin{array}{l}\text { Amount of Electricity } \\
\left(3.3 \mathrm{kWh} / 1 \mathrm{~m}^{3}\right)\end{array}$ & $\mathrm{kWh} / \mathrm{d}$ & $39,575.12$ & $\mathrm{kWh} /$ year & $14,444,918.07$ \\
\hline
\end{tabular}

Energy recovery at WWTPs represents an important policy lever for sustainability. It can be done through biogas production. The biogas produced in a digester via anaerobic digestion has the energy potential of $6.5 \mathrm{kWh} / \mathrm{m}^{3}$ (65\% methane content) and is the main 
energy source in WWTP. It was estimated that WWTPs with sludge digestion consume about $40 \%$ less net energy than wastewater treatment plant without AD digestion [22].

The Chisinau WWTP in 2018 year was consumed approximately of 19,450,795 kWh of electricity for treatment wastewater, which is about $45-50 \%$ of the overall operations and maintenances costs, then the power generated through biogas from anaerobic digestion could be helpful in reducing total energy consumption, as well as serving as an alternative power generation source.

\section{Conclusions}

Chisinau WWTP can substantially reduce grid electricity consumption, especially by utilizing biogas from anaerobic digestion. With increasing stricter discharge requirements, and aging/old infrastructure, as well as rising energy prices and concerns about climate change, Chisinau WWTP face many challenges that could significantly increase energy and costs. In additional to reduced energy consumption, anaerobic digestion at WWTP could reduce greenhouse gas emissions by decreasing the amount of grid electricity required for operations.

\section{Acknowledgments.}

This study is done within the FULBRIGHT PROGRAM at Michigan State University, Anaerobic Digestion Research and Education Center.

\section{References.}

[1] Metcalf, E. (2003) Wastewater Engineering Treatment and Reuse, $4^{\text {th }}$ ed., McGraw Hill, New York.

[2] Feasibility Study, 2011. Chisinau Water Supply and Sewage Treatment. Contract No:C21156/ECWC-2010-01-01. 
[3] Bodik, I., Kubaska, M., 2013. Energy and sustainability of operation of a wastewater treatment plant. Environment Protection Engineering, 39(2): 15-24. DOI:10.5277/EPE130202.

[4] Yang, L., Zeng, S., Chen, J., He, M. and Yang, W., 2010. Operational energy performance assessment system of municipal wastewater treatment plants. Water Science and Technology, 62(6), pp.1361-1370. https://doi.org/10.2166/wst.2010.394

[5] Mizuta, K. and Shimada, M., 2010. Benchmarking energy consumption in municipal wastewater treatment plants in Japan. Water Science and Technology, 62(10), pp.22562262. https://doi.org/10.2166/wst.2010.510

[6] Arpke, A. and Hutzler, N., 2006. Domestic water use in the United States: A life- cycle approach. Journal of Industrial Ecology, 10(1- 2), pp.169-184). https://doi.org/10.1162/108819806775545312

[7] HG nr. 950 din 25.11.13 Regulamentul privind cerințele de colectare, epurare si deversare ape uzate $\hat{\imath}$ sistemul de canalizare şi/sau în corpurile de apă pentru localitățile urbane şi rurale. Publicat: 13.03.2020 în Monitorul Oficial al Republicii Moldova Nr. 75-83 art. 219, în vigoare după modificare: 13.03.2020.

[8] HG nr.802 din 09.10.2013 Regulament privind condițiile de deversare a apelor uzate in corpurile de apa modificata prin HG nr. 862 din 08.10.2014. Publicat: 31.10 .2014 în Monitorul Oficial al Republicii Moldova Nr. 325-332 art. 946, în vigoare după modificare: 31.10.2014.

[9] Council Directive of 21 May 1991 concerning urban wastewater treatment (91/271/EEC), Published: Official Journal of the European Communities L 135, 03.05.1991, p.40 https://eur-lex.europa.eu/legal-content/EN/TXT/PDF/?uri=CELEX:31991L0271\&from=EN

[10] Henze M., Harremoës P., La Cour Jansen J. and Arvin E., Wastewater Treatment. Biological and Chemical Processes, 2nd ed., Springer-Verlag, Berlin, Heidelberg, 1997.

[11] Turovskiy I. S., Mathai P. K.. Wastewater sludge processing, 355 p.

[12] Alvarez R. E. A., Bustamante M., Kirk D., Chavarria J. A. M., Baudrit D., Pereira J. F. A., Montere W. R., Reinhold D., Liao W., Technical and economic feasibility of a solar-biopowered waste utilization and treatment system in Central America, Journal of Environmental Management 184 (2016), p.371-379. https://doi.org/10.1016/j.jenvman.2016.10.007

[13] Bustamante M., Liao W., A self-sustaining high-strength wastewater treatment system using solar-bio-hibrid power generation, Bioresource Technology 234 (2017) p.415-423. DOI:10.1016/j.biortech.2017.03.065

[14] Chen R., Rojas-Downing M., Zhong Y., Saffron C., Liao W. Life Cycle and Economic Assessment of Anaerobic Co-digestion of Dairy Manure and Food Waste, Industrial Biotechnology, Vol.11, No.2, April 2015, pag.127-139.

[15] Liu Z., Stromberg D., Liu X., Liao W., Liu Y.. A new multiple-stage electrocoagulation process on anaerobic digestion effluent to simultaneously reclaim water and clean up biogas, Journal of Hazardous Materials 285 (2015) p.486-490.

[16] Valenti F., Porto S., Dale B., Liao W., Spatial analysis of feedstock supply and logistics to establish regional biogas power generation: A case study in the region of Sicily, Renewable and Sustainable Energy Reviews 97 (2018) p.50-63. https://doi.org/10.1016/j.rser.2018.08.022

[17] Appels L., Baeyens J., Degreve J., Dewil R. Principles and potential of the anaerobic digestion of waste-activated sludge, Progress in Energy and Combustion Science 34 (2008), p.755-781. DOI: 10.1016/j.pecs.2008.06.002

[18] de Oliveira S. Jr., Exergy, Green Energy and Technology, DOI: 10.1007/978-1-44714165-5_9, Springer-Verlag London 2013, pag.281-303. 
[19] EU Reference Scenario 2016 Energy, Transport and GHG Emissions Trends to 2050. Available online: https://ec.europa.eu/energy/sites/ener/files/documents/20160713\%20draft_publication_REF2016_v13.pdf .

[20] WssTP. Water and Energy: Strategic Vision and Research Needs. The Water Supply and Sanitation Technology Platform. Available online: http://www.danishwaterforum.dk/activities/WssTP_Water_and_Energy_Publication\%2009_2011.pdf .

[21] Nowak, O., Keil, S. \& Fimml, C., Examples of energy self-sufficient municipal nutrient removal plants. Water Science and Technology 64 (1), 1-6., IWA Publishing 2011. [22] Neczaj E., Grosser A., Circular Economy in Wastewater Treatment Plant-Challenges and Barriers, presented at the 3rd EWaS International Conference on „Insights on the Water-Energy-Food Nexus", Lefkada Island, Greece, 27-30 June 2018.

[23] Indicatorii financiari si de producție ai activității întreprinderilor de alimentare cu apă şi de canalizare - membre ale Asociației "Moldova Apă-Canal" anul 2018. http://www.amac.md/public/files/documente/indicatorii_financiari_productie_intreprinderil or_apa_canal_membre_2018.pdfhttp://www.amac.md/public/files/documente/indicatorii_fi nanciari_productie_intreprinderilor_apa_canal_membre_2018.pdf 